\title{
Postharvest Quality of Tommy Atkins Mangoes Coated With Cassava Starch and Chitosan-Based Coatings
}

\author{
T. A. Oliveira ${ }^{1}$, C. A. Paiva ${ }^{1}$, A. C. Silva ${ }^{1}$, L. V. Nascimento ${ }^{1}$, R. H. L. Leite ${ }^{1} \&$ E. M. M. Aroucha ${ }^{1}$ \\ ${ }^{1}$ Universidade Federal Rural do Semi-Árido, Mossoró, Brazil \\ Correspondence: T. A. de Oliveira, Plant Science, Universidade Federal Rural do Semi-Árido, Mossoró, RN, \\ Brazil. Tel: 55-849-9605-3219. E-mail: thiagoagrotec@hotmail.com
}

Received: May 16, 2018

doi:10.5539/jas.v10n11p401
Accepted: June 26, $2018 \quad$ Online Published: October 15, 2018

URL: https://doi.org/10.5539/jas.v10n11p401

\begin{abstract}
This study aimed to evaluate postharvest quality of Tommy Atkins mangoes treated with starch cassava and chitosan based coatings. Mango fruits were collected at physiological maturity. After cleaning, weighing and identification, fruits were submitted to the respective treatments and stored for 35 days in the Laboratório de Tecnologia de Alimentos, with weekly evaluations under refrigeration $13 \pm 1^{\circ} \mathrm{C}$ and $90 \pm 5 \% \mathrm{RH}$. The experiment was conducted in a completely randomized design, in factorial scheme with four treatments: control, cassava starch $(\mathrm{CS})$, chitosan $(\mathrm{CH})$, and cassava starch/chitosan $(\mathrm{CS} / \mathrm{CH})$ at a concentration of $2 \%$, and six storage periods $(0,7,14,21,28$ and 35 days) with four replications. Fruits were evaluated in: appearance, weight loss, external color: luminosity and $\Delta \mathrm{E}$, pulp firmness, titratable acidity, soluble solids content, starch, total soluble sugars, reducing sugars and sucrose. Data were submitted to analysis of variance using SISVAR software and compared by Scott-Knott test at 5\% of probability. It was observed a reduction in appearance, pulp firmness, titratable acidity, starch and reducing sugars and increase in weight loss, luminosity, $\Delta \mathrm{E}$, soluble solids, total soluble sugars and non-reducing sugars during storage. $\mathrm{CS} / \mathrm{CH}$ coated fruits reported higher notes of appearance, lower weight loss and maintained color. Quality of physicochemical attributes: soluble solids, starch, total soluble sugars, reducing sugars and non-reducing sugars were strongly retarded.
\end{abstract}

Key words: Mangifera indica L., shelf life, conservation

\section{Introduction}

Mango (Mangifera indica L.) is one of the most important tropical fruits, appreciated for its taste, aroma, and its typical and attractive colors. World production of mango in 2014 reached over 45 millions of tons, with India as the largest producer holding $40 \%$ out of the total. Other important producers of mango worldwide are China (10\%), Thailand (8\%), Indonesia (5\%), Mexico (4\%), Pakistan (4\%), and Brazil (3\%) (FAO, 2017). Brazil exports 9\% of what it is produced, with Europe being its biggest importer (Gallo, 2015; FAO, 2017).

Tommy Atkins is the main commercial cultivar exported from Brazil, which has good productivity and capacity to adapt itself to different growing environments, tolerance to diseases, and good postharvest conservation (Andrade et al., 2017). As a climacteric fruit, it quickly ripens in adverse climatic conditions. Decrease in respiratory rate is the main technique used to extend shelf life of fruits and vegetables (Siddiqui, 2017). Currently, refrigeration under 10 to $13{ }^{\circ} \mathrm{C}$ and $85 \%$ of $\mathrm{RH}$ guarantee mangoes' quality for two to three weeks, depending on maturation stage (Neves, 2009) or refrigeration associated to carnauba wax and plastic packages, which maintain quality for 28 to 35 days, being both used to increase postharvest quality in mangoes fruits intended to exportation.

The use of edible coatings on postharvest conservation of fruits has been announced as an emerging technology with great potential, mainly for use in tropical fruits (Fani et al., 2017; Siddiq et al., 2017). Edible coatings used in postharvest are biodegradable, derived from renewable sources and avoid environmental pollution (Salgado et al., 2015; Kerch, 2015). Studies have been developed aiming tests with edible coatings to increase the use and extend shelf life of fresh products (Dhital et al., 2017; Allegra et al., 2017; Murmu \& Mishra, 2017).

Edible coatings do not want to replace conventional materials or even eliminate the use of cold environments, but it presents a functional and supporting performance, since both are capable of reducing fruit weight loss during storage or decrease oxygen absorption and retard respiration, retarding maturation and any alteration in firmness, color, weight, and chemical compounds (Cazón et al., 2017; Yousuf et al., 2018). 
Many biopolymers have been assessed on coating formulations. Cassava starch and chitosan have been studied as a primary material on these edible coatings preparation (Castro et al., 2017; Silva et al., 2017; Nair et al., 2018) because they form a resistant and transparent film with good aspect and intense brightness, turning fruits and vegetables more commercially attractive (Garcia et al., 2016).

The use of composite coatings extends quality attributes and increase postharvest shelf life of Tommy Atkins and Palmer mangoes (Azerêdo et al., 2016; Cissé et al., 2015; Medeiros et al., 2012). The combined use of these coatings promoted a uniform and homogenous coat, improving appearance and conservation of fruits quality (Castañeda, 2013).

Due to the importance of mangoes in agribusiness and its perishable nature, the objective of this study is to evaluate postharvest of Tommy Atkins mangoes using cassava starch and chitosan-based coatings.

\section{Material and Methods}

The present study was carried out in the Laboratório de Tecnologia de Alimentos at Universidade Federal Rural do Semi-Árido (UFERSA). Materials used in edible coatings formulation were: cassava starch, chitosan, and bidistilled white glycerin. Tommy Atkins mango fruits were collected at physiological maturity at Fazenda Finobrasa Agroindustrial S/A, located in Ipanguaçu-RN, in the region known as Vale do Açu, semiarid region, classified as "BSwh" according to Köppen-Geiger classification system, dry and hot, with average rainfall rate of $585.5 \mathrm{~mm}$, average annual temperature of $28.1{ }^{\circ} \mathrm{C}$, and relative humidity of $70 \%$.

In the Laboratório de Tecnologia de Alimentos, fruits were selected and washed in 100-ppm chlorine water and dried at room temperature. Fruits were marked and separated according to the experimental design chosen. The experiment was conducted under a complete randomized factorial design, in factorial scheme, with four treatments: control group (uncoated), and coatings with cassava starch (CS), chitosan (CH), and cassava starch/chitosan $(\mathrm{CS} / \mathrm{CH})$, all at a concentration of $2 \%$, and six storage periods $(0,7,14,21,28$, and 35 days $)$ under refrigeration of $13 \pm 1{ }^{\circ} \mathrm{C}$ and $90 \pm 5 \%$ of $\mathrm{RH}$, with four replicates per each experimental unit.

Coatings of cassava starch $(\mathrm{CS})$ and chitosan $(\mathrm{CH})$ were prepared with $2.0 \mathrm{~g}$ of polymer, $0.2 \mathrm{~g}$ of plasticizer (glycerol), in $97.8 \mathrm{~g}$ of distilled water (for CS) and $97.8 \mathrm{~g}$ of acetic acid (1\%) pH 3.0 (for $\mathrm{CH}$ ). Cassava starch solution was stirred and heated to $70{ }^{\circ} \mathrm{C}$ for 15 minutes using a heater-stirrer. While solution of chitosan was homogenized using a stirrer for 45 minutes until complete homogenization. After preparation of each solution separately, mixture of $\mathrm{CS} / \mathrm{CH}$ was prepared.

Fruits were individually immersed for one minute in the respective coating solutions of each treatment and dried out in room temperature for one hour, followed by storage under refrigeration at $13 \pm 1^{\circ} \mathrm{C}$ and $90 \pm 5 \% \mathrm{RH}$.

The following physicochemical analysis were made for each period of storage: appearance, weight loss, external color: luminosity and total color difference $(\Delta \mathrm{E})$, pulp firmness, titratable acidity, soluble solids content, starch, total soluble sugars, reducing sugars, and sucrose.

External appearance (EA): Fruits were evaluated by using a subjective and visual scale, according to defects severity on fruit surface (depressions, wilt, fungal injuries, and spots). Scale from 1 to 9: 9-extremely good (free from injuries, spots or rot); 8-very good (free from spots and small slight decrease in turgidity); 7-good (few spots and $5 \%$ of decrease in turgidity); 6-regular (few spots (5\%) and crinkles $(5 \%)) ; 5$-acceptable (10\% of spots-limit of acceptance); 4-bad ( $25 \%$ of spots, injuries, crinkles and softening); 3 -very bad ( $50 \%$ of spots and/or crinkles); 2 -extremely bad (75\% of damage, injuries or crinkles and softening); 1 -awful (more than $75 \%$ of damage, unacceptable). Fruits with score lower than 4 were considered inappropriate for commercialization (Lima et al., 2012).

Weight loss (WL): Determined by the difference between initial weight and weight at each period of storage, expressed in percentage (\%).

External color (EC): Measured by reflectometry, using a colorimeter CR-10 (Konica Minolta ${ }^{\circledR}$, Japan), calibrated in white porcelain surface under light conditions. Readings were expressed in $L, a^{*}$ and $b^{*}$ module, which, according to CIE (Commission Internacionale de L'Eclaraige), define color: L corresponds to luminosity (brightness, clarity and reflectance; $0=$ dark/opaque and $100=$ white) (Minolta Corp, Ltd., Japan). Readings were made in four different equidistant points, in greenish areas, and it was considered the average of readings. From coordinates it was possible to determine the total color difference with the following equation: $\Delta \mathrm{E}=$ $\sqrt{(\Delta \mathrm{L})^{2}+(\Delta \mathrm{a})^{2}+(\Delta \mathrm{b})^{2}}$, where $\Delta \mathrm{E}$ represents the difference between each color coordinate from samples at time zero and stored samples. 
Pulp firmness (PF): Pulp firmness measure was made based on penetration resistance, using an $8 \mathrm{~mm}$-tip McCormick penetrometer (FT 327 model analogic), in equatorial regions of the fruit, with two measurements per fruit. Results were expressed in Newton (N).

Titratable acidity (TA): Measured by titration of a sample of $10 \mathrm{~g}$ of juice, duplicated, added with $40 \mathrm{~mL}$ of distilled water and titrated with $\mathrm{NaOH} 0,02 \mathrm{~mol} / \mathrm{L}$ until $\mathrm{pH}$ reached 8.1 ( $\mathrm{pH}$ measured with a digital $\mathrm{pHmeter}$ ). Results were expressed in citric acid percentage, according to IAL (2008) methodology.

Soluble solids (SS): Whole fruits were processed in a processor and measured with a digital refractometer model PR-100 Palette (AttagoCo. Ltd, Japan), of automatic temperature correction and reading range from 0 to $32{ }^{\circ} \mathrm{Brix}$. Results were expressed in percentage (\%) (AOAC, 2005).

Starch content: Determined according to Figueira (2009) modified methodology. Samples constituted of 0.2 to $1.0 \mathrm{~g}$ of fruit's pulp in $50 \mathrm{~mL}$-volumetric flask. $15 \mathrm{~mL}$ of calcium chloride/acetic acid solution $(40 \%$ of calcium chloride adjusted $\mathrm{pH}$ of 3.0 with solution of $0.033 \mathrm{~mol} / \mathrm{L}$ acetic acid) was added in each flask. After homogenization, capped flasks were heated in boiling water bath for 15 minutes. Then, flasks were cooled in running water until reach room temperature and $10 \mathrm{~mL}$ of $0.033 \mathrm{~mol} / \mathrm{L}$ acetic acid solution (in sample) and deionized water (control) to complete $50 \mathrm{~mL}$ were added. Except in the control (no sample), $10 \mathrm{~mL}$ of iodide/iodate potassium solution $(10 \mathrm{~mL}$ of $10 \%$ potassium iodide in $90 \mathrm{~mL}$ of deionized water and $100 \mathrm{~mL}$ of $0.0017 \mathrm{~mol} / \mathrm{L}$ potassium iodate) was added and filled with deionized water. After homogenization, absorbance of solutions was measured at $700 \mathrm{~nm}$ in intervals of 10 to 20 minutes after addition of iodide/iodate. Starch content was expressed in \%.

Total, reducing and non-reducing sugars: Measured, respectively, by Antrona and Somogy-Nelson methods, with results expressed in percentage. Sucrose was determined by the difference between total sugars and reducing sugars, with results expressed in percentage.

Data were submitted to variance analysis using the SISVAR 5.6 software (Ferreira, 2011). Treatments were compared by Scott-Knott test at $5 \%$ of probability.

\section{Results and Discussion}

\subsection{External Appearance}

A reduction on the external appearance was observed in coated fruits from day 21, differing from fruits of control group, which with seven days of storage began to decrease scores of external appearance (Figure 1).

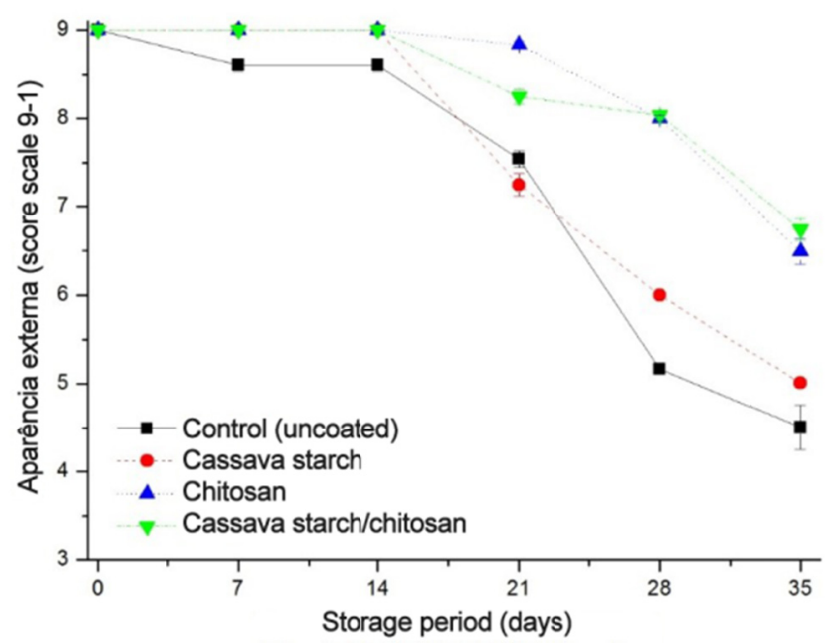

Figure 1. Appearance score scale (9-1) of Tommy Atkins mangoes stored with different coatings in function of period of stored $\left(13^{\circ} \mathrm{C}\right.$ and $\left.90 \% \mathrm{RH}\right)$. Mossoró-RN, UFERSA, 2017

At day 21 of storage, fruits coated with chitosan and $\mathrm{CS} / \mathrm{CH}$ showed superior scores than fruits from control and coated with cassava starch. We may observe that coatings with chitosan results in scores higher than the mixtures, what is caused by the characteristic of chitosan coatings to let fruits brighter. 
Coated fruits maintained superior scores of external appearance than fruits from control at day 28. However, cassava starch coating demonstrated better results than fruits from control group, but had lower scores when compared to others coatings, which presented uniformity on maintaining external appearance.

At day 35 of storage, even with decrease in appearance scores of all fruits, only coated fruits were marketable (appearance scores greater than 5.0). We verified that the storage of fruits coated with chitosan and $\mathrm{CS} / \mathrm{CH}$ were more promising on maintaining external appearance for longer periods when compared to uncoated and fruits coated only with cassava starch. According to Castañeda (2013) the use of coatings with $2 \%$ of cassava starch/chitosan ensures more brightness to apples throughout storage.

Similar results were observed by Medeiros et al. (2012), and Amariz et al. (2010) in Tommy Atkins mangos, who indicated the use of chitosan, pectin, carboxymethyl cellulose and dextrin based coatings obtained higher scores for external appearance through storage period compared to uncoated fruits.

\subsection{Weight Loss}

There was increase in weight loss during the period of storage regardless of treatments (Figure 2). At day 7 , fruits coated with chitosan and $\mathrm{CS} / \mathrm{CH}$ had similar weight loss between each other, and lower weight loss than fruits coated with cassava starch and control.

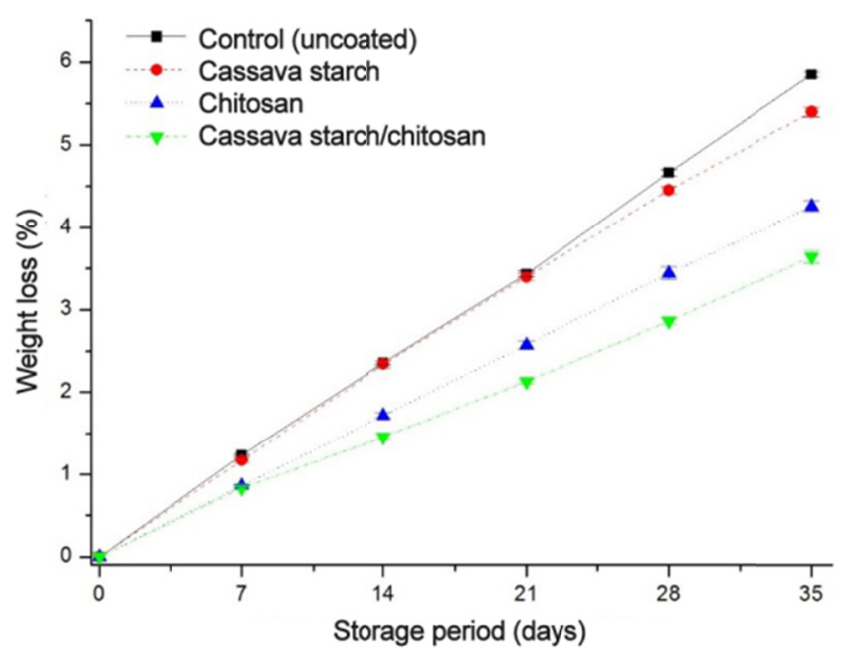

Figure 2. Weight loss (\%) of Tommy Atkins mangoes stored with different coatings in function of period of stored at $13{ }^{\circ} \mathrm{C}$ and $90 \%$ RH. Mossoró-RN, UFERSA, 2017

Even with reported results for fruits coated with cassava starch showing similar weight loss to control group at day 21, day 28 and 35 this treatment decreased weight loss of fruits.

Notwithstanding, coatings containing chitosan were more effective in stopping weight loss. At day $14, \mathrm{CS} / \mathrm{CH}$ coating was more efficient in halting weight loss compared to other treatments. It halted $38 \%$ of loss at 35 days compared to control, $35 \%$ compared to fruits coated with cassava starch, and 15\% compared to chitosan.

Transpiration process depends on water vapor gradient between the atmosphere and fruit tissue (Siddiqui, 2016). Edible coatings act as a barrier to the fruit's surface, reducing the loss of water, sealing small injuries and retarding weight loss.

Hydrophilicity of both polymers separately turns them into a poor barrier due to a low efficiency in restraining water vapor loss (Assis \& Brito, 2014). The effect of mixed coating, cassava starch and chitosan, is related to interactions of hydrogen bonds linkages between cassava starch and chitosan, which reduce the availability of hydrophobic groups, decreasing its interactions with water molecules and lowering water vapor rate, reducing weight loss of fruits and vegetables (Cazón et al., 2017).

Campo et al. (2011) observed lower weight loss in strawberries during storage with the mixture of cassava starch $(2 \%)$ and chitosan $(1 \%)$ when compared to same coatings separately. 
Throughout storage, there was an increase in weight loss of mango fruits regardless of coating used. At the end of storage the greatest weight loss was reported in fruits from the control group (5.85\%) followed by cassava starch (5.39\%), and the lowest loss was seen in fruits coated with CS/CH (3.65\%).

The use of composite edible coatings guarantee a lower loss of weight in fruits such as in bananas coated with arabic gum and chitosan-based coatings (Maqbool et al., 2011), in grapes coated with chitosan and glucose (Gao et al., 2013), and in different cultivars of mangos coated with chitosan combined with pectin, cassava starch, arabic gum and lactoperoxidase (Medeiros et al., 2012; Azerêdo et al., 2016; Khaliq et al., 2016; Cissé et al., 2015).

\subsection{Color-Lightness- $\Delta E$}

There was a significant interaction between treatment and periods of storage factors for lightness and $\Delta \mathrm{E}$. Fruits from control and fruits coated with cassava starch showed lightness values of 57.53 and 56.38 at day 14, higher than fruits coated with chitosan (50.85) and with $\mathrm{CS} / \mathrm{CH}$ (49.38), which did not differ from each other. From day 14 to the end of storage, coatings of chitosan and $\mathrm{CS} / \mathrm{CH}$ retarded ripening of fruits. This may be caused by a progressive or nearly no change in lightness, differently from what was seen in uncoated fruits and cassava starch-coated fruits, which had a continuous increase in lightness until the end of storage.

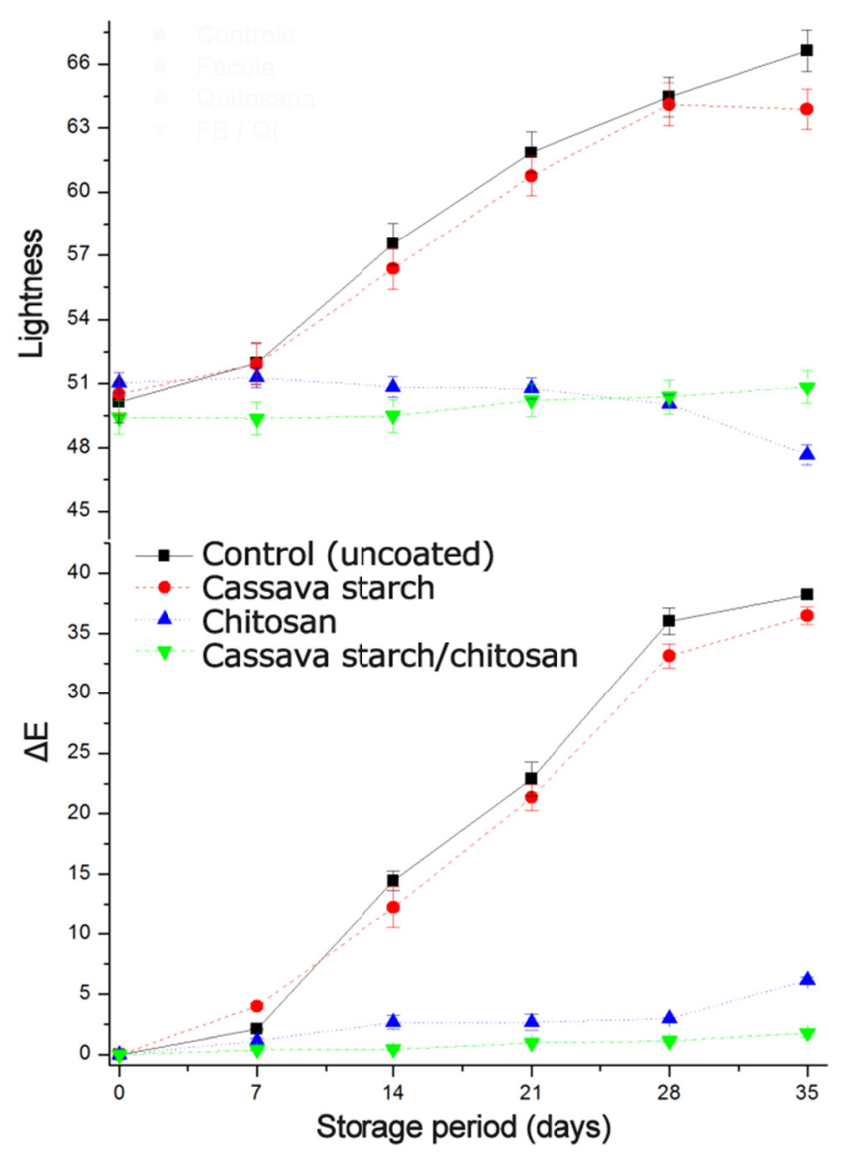

Figure 3. Lightness and $\Delta \mathrm{E}(\%)$ of Tommy Atkins mango skins stored with different coatings in function of period of stored at $13{ }^{\circ} \mathrm{C}$ and $90 \%$ RH. Mossoró-RN, UFERSA, 2017

According to Nunes et al. (2007), lightness value for Tommy Atkins mangos increases during storage at $20{ }^{\circ} \mathrm{C}$ because fruits skin color is dark green when harvested, with ripening fruits turning lighter due to evolution of a yellowish color. Fruits coated with chitosan and $\mathrm{CS} / \mathrm{CH}$ maintained initial values of lightness, what indicates preservation of chlorophyll and reduction of the carotenoids synthesis process, which is caused by the formation of a protective layer that promotes a modified atmosphere, decreasing respiration rate of fruits, and so retarding ripening. 
The color is a very important indicator of ripening and identifies its quality and acceptability of consumers. The total color difference $(\Delta \mathrm{E})$ is widely used to determine the ripening process due to the degradation of chlorophyll and carotene formation (Siddiqui, 2017). It was observed $\Delta \mathrm{E}$ values in fruits coated with chitosan (1.13) and $\mathrm{CS} / \mathrm{CH}(0.38)$ inferior to the other treatments, however, fruits uncoated had $\Delta \mathrm{E}$ of 2.08 , a value lower than the observed in fruits coated with cassava starch (3.98).

Treatments differ within each other from day 14 to the end of storage. The lowest values of $\Delta \mathrm{E}$ were in fruits coated with $\mathrm{CS} / \mathrm{CH}$. Comparing initial color, throughout storage period, fruits coated with $\mathrm{CS} / \mathrm{CH}$ were apparently unchanged (1.8), with a significant delay of color changing, when compared to chitosan coating (6.29), cassava starch (36.48), and uncoated (38.23).

Similar results were also reported by Ali et al. (2011), a delay in color development of papaya fruits coated with high concentrations of chitosan due to the low respiration rate and reduction of ethylene production. Maqbool et al. (2011), using an arabic gum/chitosan coatings in banana, had the best results for the delay in color change throughout the storage period.

The relative delay in ripening and fruit senescence, resulting in a reduction in color change, is associated to high levels of $\mathrm{CO}_{2}(>1 \%)$ and a decrease of oxygen levels in fruits tissues due to the coatings. It retards the skin color evolution in banana and in papaya because of the lower respiration rate and reduction in ethylene production (Wills \& Golding, 2016).

\subsection{Firmness}

Mango fruits presented firmness values varying with the type of coating used and the storage period (Figure 4). It is noted a significant difference at day 7 , with fruits from control reporting pulp firmness $(82.84 \mathrm{~N})$ lower than fruits coated with chitosan $(119.54 \mathrm{~N})$, cassava starch $(105.64 \mathrm{~N})$, and cassava starch/chitosan $(102.03 \mathrm{~N})$.

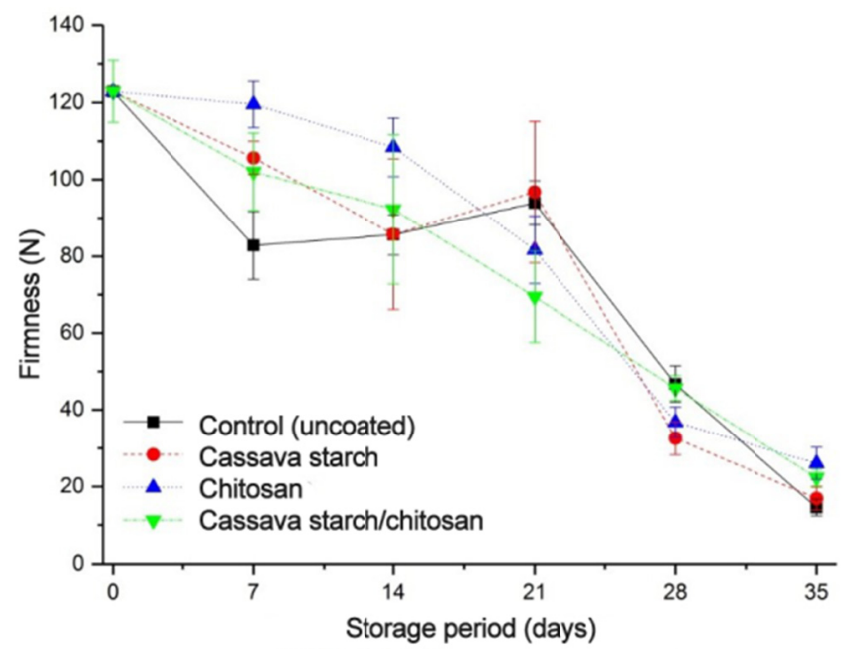

Figure 4. Pulp firmness (Newton) of Tommy Atkins mangoes stored with different coatings in function of period of stored at $13{ }^{\circ} \mathrm{C}$ and $90 \% \mathrm{RH}$. Mossoró-RN, UFERSA, 2017

At day 14 of storage, treatments coated with chitosan showed values of firmness superior than the other treatments, which did not differ from each other. At day 21, fruits from control and coated with cassava starch showed higher firmness values than the other treatments, with no statistical difference between treatments and storage period at day 28 and 35 .

Lima et al. (2012) verified at 12 days of storage of Tommy Atkins mangos at $10{ }^{\circ} \mathrm{C}$ and $88 \% \mathrm{RH}$ that fruits from control group were superior in firmness than fruits coated with cassava starch. Positive results of coating were demonstrated by Souza et al. (2011) in Tommy Atkins mangoes coated with $1.5 \%$ chitosan stored for nine days at $23{ }^{\circ} \mathrm{C}$. These authors reported positive effect on maintaining values of firmness in fruits coated when compared to uncoated fruits.

Figure 4 shows the reduction of $122.88 \mathrm{~N}$ of pulp firmness regardless of the treatment used, to $14.68,16.96$, 26.13, and $22.41 \mathrm{~N}$, which did not statistically differ from each other at the end of storage. In mangoes, the gene related to firmness is triggered by ethylene, being directly related to the presence of water within cells, i.e., with 
cell turgor, which decreases with storage time (Siddiq et al., 2017). The decrease in firmness is also associated to the transformation of insoluble pectic fractions to soluble forms during ripening (Siddiqui, 2017).

\subsection{Titratable Acidity}

The use of coatings influenced titratable acidity of fruits during storage (Table 1). At day 14, the type of coating did not change acidity of fruits. However, at day 21 and 28 fruits coated with cassava starch and control reported values statistically superior to the other treatments, which changed in day 35 , when fruit acidity did not differ within treatments.

Table 1. Titratable acidity (\% acid citric) of Tommy Atkins mangoes stored with different coatings in function of period of stored at $13{ }^{\circ} \mathrm{C}$ and $90 \% \mathrm{RH}$. Mossoró-RN, UFERSA, 2017

\begin{tabular}{lllll}
\hline Storage period & \multicolumn{4}{c}{ Coatings } \\
\cline { 2 - 5 } & Control & CS & CH & CS/CH \\
\hline 0 & $0.745 \mathrm{aC}$ & $0.745 \mathrm{aB}$ & $0.745 \mathrm{aB}$ & $0.745 \mathrm{aB}$ \\
7 & $0.650 \mathrm{aC}$ & $0.783 \mathrm{aB}$ & $0.650 \mathrm{aC}$ & $0.748 \mathrm{aB}$ \\
14 & $1.170 \mathrm{aA}$ & $1.103 \mathrm{aA}$ & $1.205 \mathrm{aA}$ & $1.173 \mathrm{aA}$ \\
21 & $1.175 \mathrm{aA}$ & $1.028 \mathrm{bA}$ & $0.735 \mathrm{cB}$ & $0.700 \mathrm{cB}$ \\
28 & $0.850 \mathrm{aB}$ & $0.830 \mathrm{aB}$ & $0,553 \mathrm{bC}$ & $0.623 \mathrm{bC}$ \\
35 & $0.465 \mathrm{aD}$ & $0.500 \mathrm{aC}$ & $0.613 \mathrm{aC}$ & $0.545 \mathrm{aC}$ \\
\hline
\end{tabular}

Note. * Averages followed by same lowercase letter within lines and same uppercase letter within column did not differ from each other by Scott-Knott test $(\mathrm{p}<0.05)$.

Decrease in titratable acidity of fruits coated with chitosan and its mixture with cassava starch from day 21 and fruits coated with cassava starch at day 28 is probably related to the used of acids as carbon skeleton in the respiratory process. The level of acids in plants may decrease with maturation, due the transformation of acids in substrate for phenolic compounds synthesis, lipids, and vegetal aromas (Siddiqui, 2017).

On the other side, an increase in acidity was observed at day 14 in mango fruits regardless of its coating, with reduction of acidity after that period of storage. Fruits did not differ in titratable acidity values within coatings at day 35 of storage. Silva et al. (2017) showed similar results and reported that the increase in acidity of fruits may be assigned to galacturonic acid, from pectin degradation.

Gol and Rao (2014), studying coatings, reported that mangoes reach a lower level of titratable acidity $(0.2 \%)$ at 18 days of postharvest storage. The decline in titratable acidity during storage was assigned to the use of acids as substrates for respiration, as well as its conversion to sugar via gluconeogenesis (Eskin et al., 2013).

\subsection{Soluble Solids}

There was effect of type of coating and storage period on the soluble solids content of fruits (Figure 5). 


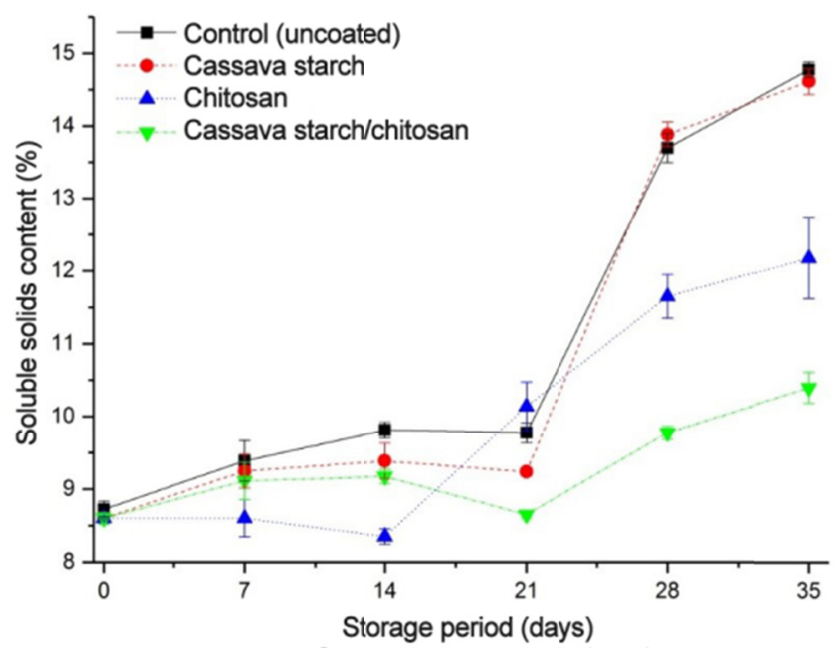

Figure 5. Soluble solids content (\%) of Tommy Atkins mangoes stored with different coatings in function of period of stored at $13{ }^{\circ} \mathrm{C}$ and $90 \%$ RH. Mossoró-RN, UFERSA, 2017

There was a significant difference within treatments at day 14 of storage. Treatment with chitosan coating showed the lowest values of soluble solids $(8.35 \%)$ at day 28 , statistically differing from the others. At day 21 , fruits coated with cassavas starch and $\mathrm{CS} / \mathrm{CH}$ had inferior soluble solids values $(9.24$ and $8.65 \%$, respectively) compared to fruits coated with chitosan $(10.14 \%)$ and uncoated fruits $(9.78 \%)$, which did not differ from each other.

The soluble solids content of $\mathrm{CS} / \mathrm{CH}$ fruits were $9.78 \%$ at day 28 and $10.39 \%$ at day 35 , the lowest values when compared to other treatments. Coating significantly delayed SS changes in comparison to fruits at the end of storage. During the ripening, process carbohydrates are transformed into simple sugars, resulting in an increase of soluble solids. Khaliq et al. (2016), using arabic gum/chitosan coating, delayed the soluble solid increase in mango fruits.

Soluble solids concentration progressively increased with increase in storage period, regardless of coating used. However, this increasing tendency was more expressive in fruits from the control group. In all of the storage periods evaluated, there was a tendency to increase values of soluble solids, with the lowest values reported by fruits coated with $\mathrm{CS} / \mathrm{CH}$ when compared to control, cassava starch, and chitosan. This way, $\mathrm{CS} / \mathrm{CH}$ treatment resulted in lower values of soluble solids when compared to other treatments at day 35, suggesting that fruits from these treatments reduced their metabolic processes.

These results match the ones from Azerêdo et al. (2016), who pointed out that Tommy Atkins mango fruits coated with a mix of cassava starch and chitosan presented lower buildup of soluble solids at the end of storage. Which is supported by Silva et al. (2017), who working with postharvest in Palmer mangoes coated with different concentrations of chitosan verified that coatings with 2 and $3 \%$ of chitosan maintain increase in soluble solids during storage.

Soluble solids concentration increased during ripening, due to starch hydrolysis, since glucose and fructose are the main monosaccharides, and sucrose is the main disaccharide resulted from this process. Increase in SS concentration may be assigned to carbohydrates degradation into simple sugars and glucose (Wills \& Golding, 2016).

The low respiration rate reduces metabolism processes, resulting in lower concentration of soluble solids and slow conversion of carbohydrates into sugars (Siddiqui, 2017). Sugar/acid ratio has a significant role in the determination of fruit ripening and fruit flavor. The edible coating created a semipermeable film around the fruit and modified internal atmosphere, decreasing concentration of $\mathrm{O}_{2}$ and increasing production of $\mathrm{CO}_{2}(\mathrm{Medeiros}$ et al., 2012).

\subsection{Starch}

There was significant interaction between type of treatment and period of storage (Figure 6). 


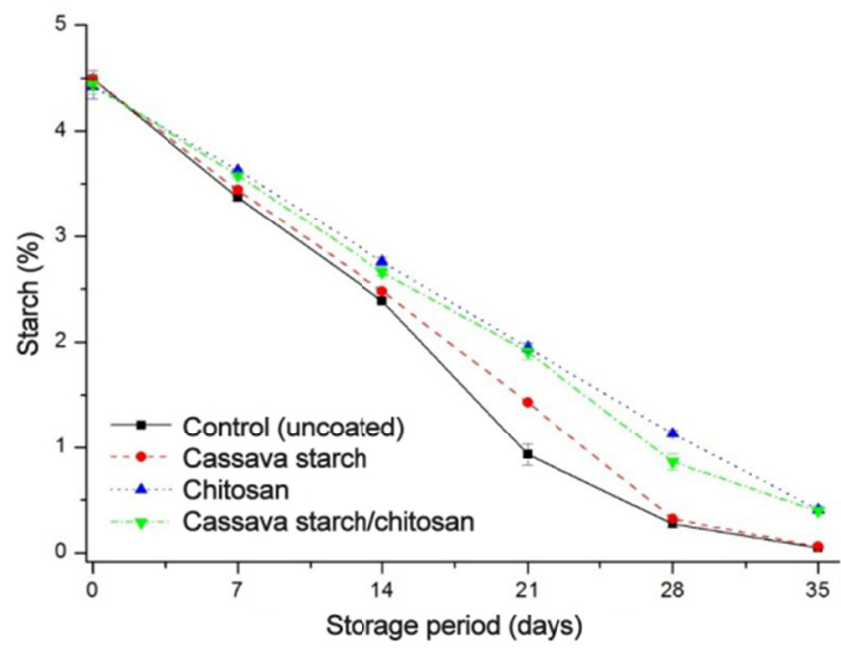

Figure 6. Starch content (\%) of Tommy Atkins mangoes stored with different coatings in function of period of stored at $13{ }^{\circ} \mathrm{C}$ and $90 \%$ RH. Mossoró-RN, UFERSA, 2017

There was a reduction of starch content in fruits during the period of storage regardless of treatment applied. Siddiq et al. (2017), during growth of mango on trees, reported an increase in starch content, from $1 \%$ to $13 \%$. Starch is accumulated during fruit maturation and ripening. The starch suffers hydrolysis and forms sugars. Degradation of starch is related mainly to the $\alpha$-amylase enzyme, and $\beta$-amylase (Wills \& Golding, 2016).

The result from this conversion is the increase of soluble solids content (Silva et al., 2017). In addition to this, it is possible that there is also a direct relation between starch degradation and softening of fruit pulp.

At day 14 of storage, there was a significant difference within treatments. Chitosan-coated fruits $(2.76 \%)$ and $\mathrm{CS} / \mathrm{CH}(2.66 \%)$ reported superior starch values when compared to other treatments. From day 21, the same behavior was reported for starch values of each period of storage.

The benefit of using edible coatings include reduction of respiration, which causes metabolic reactions to the lower level of $\mathrm{O}_{2}$, decreasing starch degradation (Figure 6) and sugar consumption (Figure 7). The reduction of respiration rate with the mixture of coatings decreases tissue deterioration, extending the shelf life of fruits (Siddiqui, 2016).

Similar results were observed by Silva et al. (2017), which the reported reduction was revealed in starch degradation of Tommy Atkins mangoes coated with different chitosan concentrations, in refrigerated storage.

\subsection{Total Soluble Sugars, Reducing Sugars, and Sucrose}

Significant interaction was verified between type of coating and storage period (Figures 7a-7c).

Total soluble sugars content (TSS) and sucrose (SU) increased throughout storage. However, the increase of reducing sugars occurred only until day 21 for all treatments, with a decline in fruits coated with cassava starch and control; and at day 28 for fruits coated with chitosan. With no decline registered for fruits coated with cassava starch/chitosan. This reduction in reducing sugars suggests consumption of glucose, which is used in the process of respiration (Siddiqui, 2017).

When looking at treatments within each period of storage, it is noted that at day 14 there was a significant difference in TSS and SU. Fruits coated with chitosan and CS/CH had lower values of TSS and SU, statistically different from the others.

At day 21, TSS, and day 28, SU, until the end of storage, fruits coated with $\mathrm{CS} / \mathrm{CH}$ had the lowest values for total soluble sugars and sucrose, differing from other treatments. Sugars that are present in mango fruits: glucose, fructose, and sucrose, with the last one mentioned present in larger quantity, showing great contribution on soluble solids and total soluble sugars (Silva et al., 2017). It is expected to see an increase in levels of TSS and sucrose through storage time in fruits with starch reserve, as it happens in climacteric fruits, such as banana (Wills \& Golding, 2016). 
A

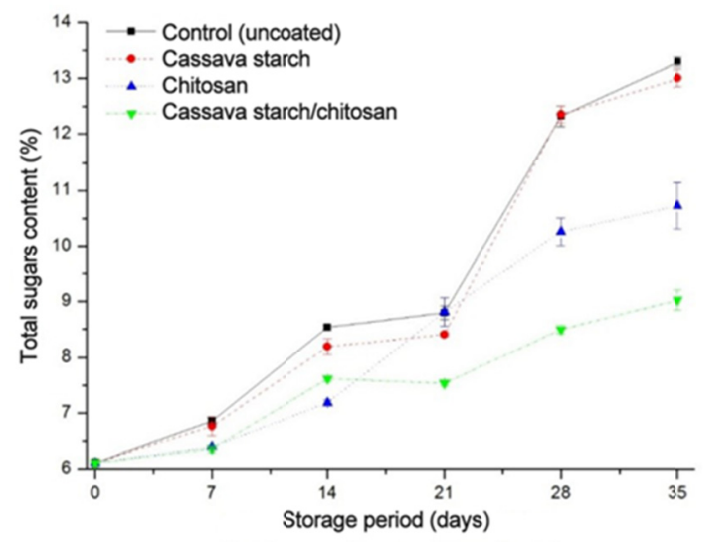

B

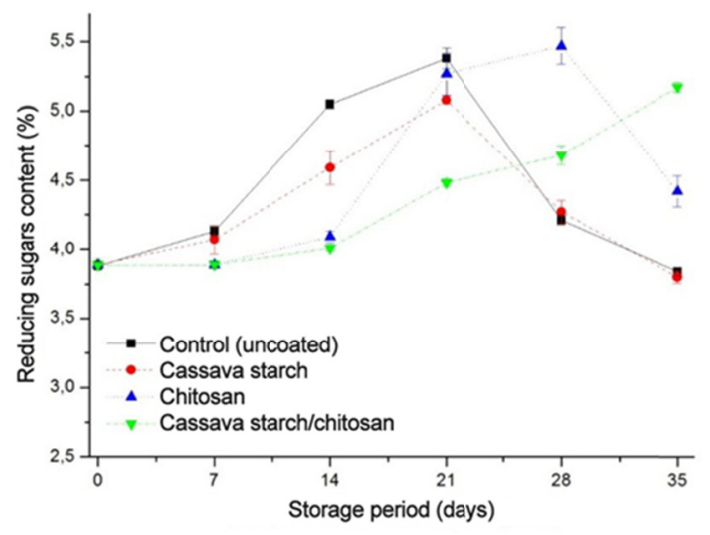

C

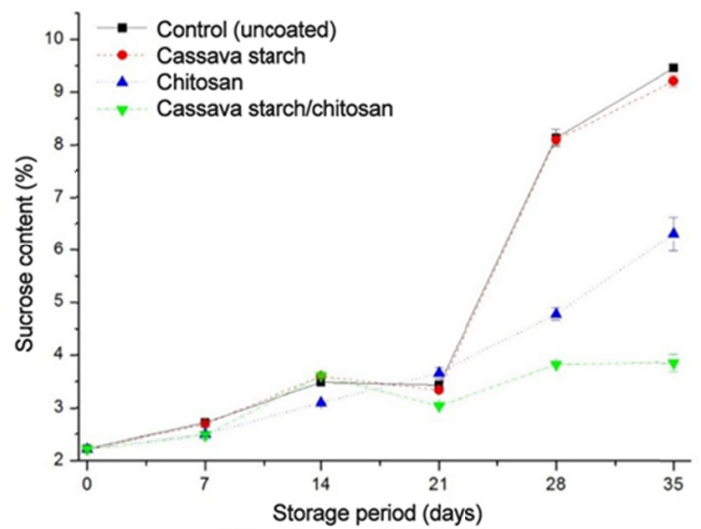

Figure 7. Total soluble sugars (a), reducing sugars (b) and sucrose (c) of Tommy Atkins mangoes stored with different coatings in function of period of stored at $13{ }^{\circ} \mathrm{C}$ and $90 \%$ RH. Mossoró-RN, UFERSA, 2017

Fruits treated with $\mathrm{CS} / \mathrm{CH}$ presented the best effect in retarding the consumption of important nutrients, such as TSS, SU, and reducing sugars. This may be due to the alteration on respiration, reducing metabolic activity. Gao et al. (2013) reported that coating with chitosan/glucose was more efficient in retarding changes in soluble solids in grape fruits during storage when compared to chitosan and glucose separately.

Abbasi et al. (2009) studied the effect of chitosan coatings on postharvest quality of mango fruits and observed that reducing sugars, sucrose, and total soluble sugars were lower in fruits coated with the protective layer. Gol and Rao (2014) verified that when using 5\%-zein and 10\%-gelatin based coatings mango fruits were more efficient in retarding buildup of total soluble sugars, reducing sugars, and sucrose. Similar results were reported by Silva (2015) when using different coatings as a protective layer on Palmer mangoes conservation.

\section{Conclusion}

Cassava starch/chitosan coating reported higher scores for appearance, lower weight loss and maintained fruit color. Physicochemical quality attributes: soluble solids, starch, total soluble sugars, reducing sugars and non-reducing sugars were strongly retarded.

\section{References}

Abbasi, N. A., Iqbal, Z., Maqbool, M., \& Hafiz, I. A. (2009). Postharvest quality of mango (Mangifera indica L.) fruit as affected by chitosan coating. Pakistan Journal of Botany, 41, 343-357.

Ali, A., Muhammad, M. T. M., Sijam, K., \& Siddiqui, Y. (2011). Effect of chitosan coatings on the physicochemical characteristics of Eksotika II papaya (Carica papaya L.) fruit during cold storage. Food Chemistry, 124, 620-626. https://doi.org/10.1016/j.foodchem.2010.06.085 
Allegra, A., Sortino, G., Inglese, P., Settanni, L., Todaro, A., \& Gallotta, A. (2017). The effectiveness of Opuntia ficus-indica mucilage edible coating on post-harvest maintenance of 'Dottato'fig (Ficus carica L.) fruit. Food Packaging and Shelf Life, 12, 135-141. https://doi.org/10.1016/j.fps1.2017.04.010

Amariz, A., Lima, M. A. C., Trindade, D. C. G., Santos, A. C. N., \& Ribeiro, T. P. (2010). Recobrimentos à base de carboximetilcelulose e dextrina em mangas 'Tommy Atkins' armzenadas sob refrigeração. Ciência Rural, Santa Maria, 40, 2199-2205. https://doi.org/10.1590/S0103-84782010001000024

Andrade, J. E. E. S., Costa, P. G., \& Leite, Â. A. M. (2017). Análise da estratégia de operações na produção de manga para exportação. Revista em Agronegócio e Meio Ambiente, 10, 115-136. https://doi.org/10.17765/ 2176-9168.2017v10nEd.esp.p115-136

AOAC (Association of Official Analytical Chemists). (2005). Official methods of analysis of the Association Analytical Chemists (18th ed., p. 1298). Gaithersburg: AOAC.

Assis, O. B. G., \& Britto, D. (2014). Revisão: Coberturas comestíveis protetoras em frutas:fundamentos e aplicações. Brasilian Journal Food Technology, 17, 87-97. https://doi.org/10.1590/bjft.2014.019

Azerêdo, L. P. M., Silva, S. M., Lima, M. A. C., Dantas, R. L., \& Pereirara, W. E. (2016). Qualidade de manga 'tommy atkins' da produção integrada com recoberta fécula de mandioca associada a óleos essenciais e quitosana. Revista Brasileira Fruticultura, 38, 141-150. https://doi.org/10.1590/0100-2945-270/14

Campos, R. P., Kwiatkowski, A., \& Clemente, R. (2011). Post-harvest conservation of organic strawberries coated with cassava starch and chitosan. Revista Ceres, 58, 554-560. https://doi.org/10.1590/S0034$737 \mathrm{X} 2011000500004$

Castañeda, L. M. F. (2013). Avaliação da quitosana e da fécula de mandioca, aplicada em pós-colheita no recobrimento de maçãs (Doctoral dissertation, Universidade Federal do Rio Grande do Sul, Porto Alegre, Brazil). Retrivied from http://www.lume.ufrgs.br/handle/10183/108580

Castro, M., Mantuano, M. I., Coloma, J. L., \& Santacruz, S. (2017). Utilisation of Cassava Starch Edible Films containing Salicylic Acid on Papaya (Carica papaya L.) Preservation. Revista Politécnica, 39.

Cazón, P., Velazquez, G., Ramírez, J. A., \& Vázquez, M. (2017). Polysaccharide-based films and coatings for food packaging: A review. Food Hydrocolloids, 68, 136-148. https://doi.org/10.1016/j.foodhyd.2016.09.009

Cissé, M., Polidori, J., Montet, D., Loiseau, G., \& Ducamp-Collin, M. N. (2015). Preservation of mango quality by using functional chitosan-lactoperoxidase systems coatings. Postharvest Biology and Technology, 101, 10-14. https://doi.org/10.1016/j.postharvbio.2014.11.003

Dhital, R., Joshi, P., Becerra-Mora, N., Umagiliyage, A., Chai, T., Kohli, P., \& Choudhary, R. (2017). Integrity of edible nano-coatings and its effects on quality of strawberries subjected to simulated in-transit vibrations. LWT-Food Science and Technology, 80, 257-264. https://doi.org/10.1016/j.lwt.2017.02.033

Eskin, N. A. M., Hoehn, E., \& Shahidi, F. (2013). Fruits and vegetables. In N. A. M. Eskin, \& F. Shahidi (Eds.), Biochemistry of foods (pp. 49-126). Academic Press, San Diego. https://doi.org/10.1016/B978-0-08-091 809-9.00002-9

Fani, A. A., Fortuny, R. S., \& Belloso, O. M. (2017). Nanoemulsions as edible coatings. Current Opinion in Food Science, 15, 43-49. https://doi.org/10.1016/j.cofs.2017.06.002

FAO. (2017). Food and Agriculture Organization of the United Nations Statistics Division. Retrivied from http://faostat3.fao.org/browse/Q/*/E

Ferreira, D. F. (2011). Sisvar: A computer statistical analysis system. Ciência e Agrotecnologia, 35, 1039-1042. https://doi.org/10.1590/S1413-70542011000600001

Figueira, J. A. (2009). Determinação e caracterização de amido de cana-de-açúcar e adequação de metodologia para determinação de alfa-amilase em açúcar bruto (Master's thesis, Universidade Estadual de Campinas, Campinas, Brazil). Retrivied from http://www.bv.fapesp.br/pt/publicacao/74208//

Gallo, E. (2015). Recent evolution of the world mango market. Acta Horticulturae, 1075, 41-50. https://doi.org/10.17660/ActaHortic.2015.1075.3

Gao, P., Zhu, Z., \& Zhang, P. (2013). Effects of chitosan-glucose complex coating on postharvest quality and shelf life of table grapes. Carbohydrate Polymers, 95, 371-378. https://doi.org/10.1016/j.carbpol.2013. 03.029 
Garcia, M. P. M., Gómez-Guillén, M. C., López-Caballero, M. E., \& Barbosa-Cánovas, G. V. (2016). Edible Films and Coatings: Fundamentals and Applications (1st ed.). CRC Press. https://doi.org/10.1201/97813 15373713

Gol, N. B., \& Rao, T. R. (2014). Influence of zein and gelatin coatings on the postharvest quality and shelf life extension of mango (Mangifera indica L.). Fruits, 69, 101-115.

IAL (Instituto Adolfo Lutz). (2008). Métodos químicos e físicos para análises de alimentos (6th ed.). São Paulo, SP: IAL.

Kerch, G. (2015). Chitosan films and coatings prevent losses of fresh fruit nutritional quality: A review. Trends in Food Science \& Technology, 46, 159-166. https://doi.org/10.1016/j.tifs.2015.10.010

Khaliq, G., Mohamed, M. T. M., Ding, P., Ghazali, H. M., \& Ali, A. (2016). Storage behaviour and quality responses of mango (Mangifera indica L.) fruit treated with chitosan and gum arabic coatings during cold storage conditions. International Food Research Journal, 23, 141-148.

Lima, A. B., Silva, S. M., Rocha, A., Nascimento, L. C., \& Ramalho, F. S. (2012). Conservação pós-colheita de manga 'Tommy Atkins' orgânica sob recobrimentos bioorgânicos. Revista Brasileira de Fruticultura, 34, 704-710. https://doi.org/10.1590/S0100-29452012000300008

Maqbool, M., Ali, A., Alderson, P. G., Zahid, N., \& Siddiqui, Y. (2011). Effect of a novel edible composite coating based on gum arabic and chitosan on biochemical and physiological responses of banana fruits during cold storage. Journal of Agricultural and Food Chemistry, 59, 5474-5482. https://doi.org/10.1021/ jf200623m

Medeiros, B. G. S., Pinheiro, A. C., Carneiro-Da-Cunha, M. G., \& Vicente, A. A. (2012). Development and characterization of a nanomultilayer coating of pectin and chitosan-Evaluation of its gas barrier properties and application on 'Tommy Atkins' mangoes. Journal of Food Engineering, 110, 457-464. https://doi.org/ 10.1016/j.jfoodeng.2011.12.021

Murmu, S. B., \& Mishra, H. N. (2017). Optimization of the arabic gum based edible coating formulations with sodium caseinate and tulsi extract for guava. LWT-Food Science and Technology, 80, 271-279. https://doi.org/10.1016/j.lwt.2017.02.018

Nair, M. S., Saxena, A., \& Kaur, C. (2018). Effect of chitosan and alginate based coatings enriched with pomegranate peel extract to extend the postharvest quality of guava (Psidium guajava L.) Food Chemistry, 240, 245-252. https://doi.org/10.1016/j.foodchem.2017.07.122

Neves, L. C. (2009). Manual pós-colheita da fruticultura brasileira. Londrina, PR: EDUEL.

Nunes, M. C. N., Emond, J. P., Brecht, J. K., Dea, S., \& Proulx, E. (2007). Quality curves for mango as a function of the storage temperature. Journal of Food Quality, 30, 104-120. https://doi.org/10.1111/ j.1745-4557.2007.00109.x

Salgado, P. R., Ortiz, C. M., Musso, Y. S., Giorgio, L., \& Mauri, A. N. (2015). Edible films and coatings containing bioactives. Current Opinion in Food Science, 5, 86-92. https://doi.org/10.1016/j.cofs.2015. 09.004

Siddiq, M., Brecht, J. K., \& Sidhu, J. S. (2017). Handbook of Mango Fruit: Production, Postharvest Science, Processing Technology and Nutrition. Wiley-Blackwell. https://doi.org/10.1002/9781119014362

Siddiqui, M. W. (Ed.). (2016). Eco-friendly technology for postharvest produce quality. Academic Press.

Siddiqui, M. W. (2017). Preharvest Modulation of postharvest fruit and vegetable quality (1st ed.). Cambridge: Elsevier.

Silva, A. L. (2015). Revestimentos comestiveis em mangas: propriedades e efeitos sobre a qualidade e conservação pós-colheita da fruta (Doctoral dissertation, Universidade Federal de Santa Catarina, Florianópolis). Retrivied from http://150.162.242.35/handle/123456789/169461

Silva, G. M. C., Silva, W. B., Medeiros, D. B., Salvador, A. R., Cordeiro, M. H. M., Silva, N. M., \& Mizobutsi, G. P. (2017). The chitosan affects severely the carbon metabolism in mango (Mangifera indica L. cv. Palmer) fruit during storage. Food Chemistry, 237, 372-378. https://doi.org/10.1016/j.foodchem.2017. 05.123 
Souza, M. L., Morgado, C. M. A., Marques, K. M., Mattiuz, C. F. M., \& Mattiuz, B. H. (2011). Pós-colheita de mangas 'Tommy Atkins' recobertas com quitosana. Revista Brasileira de Fruticultura, 33, $337-343$. https://doi.org/10.1590/S0100-29452011000500042

Wills, R., \& Golding, J. (2016). Postharvest: An introduction to the physiology and handling of fruit and vegetables. UNSW Press. https://doi.org/10.1079/9781786391483.0000

Yousuf, B., Qadri, O. S., \& Srivastava, A. K. (2018). Recent developments in shelf-life extension of fresh-cut fruits and vegetables by application of different edible coatings: A review. LWT-Food Science and Technology, 89, 198-209. https://doi.org/10.1016/j.lwt.2017.10.051

\section{Copyrights}

Copyright for this article is retained by the author(s), with first publication rights granted to the journal.

This is an open-access article distributed under the terms and conditions of the Creative Commons Attribution license (http://creativecommons.org/licenses/by/4.0/). 